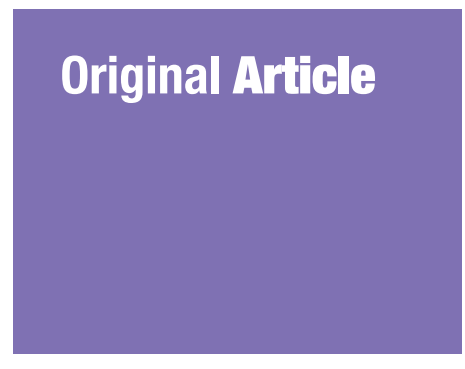

Submitted: 13 Feb 2017

Accepted: 22 Aug 2017

Online: 26 Oct 2017

\title{
Nutritional Compositions and
} Antiproliferative Activities of Different Solvent Fractions from Ethanol Extract of Cyphomandra betacea (Tamarillo) Fruit

\author{
Maisarah Abdul MutaliB ${ }^{1}$, Asmah Rahmat ${ }^{2}$, Faisal Ali, ${ }^{1,3}$, Fauziah \\ OTHMAN ${ }^{4}$, Rajesh RAMASAMY ${ }^{5}$
}

Department of Nutrition and Dietetics, Faculty of Medicine and Health Sciences, Universiti Putra Malaysia, 43400 UPM, Serdang Selangor, Malaysia

2 Faculty of Science Technology and Human Development, Universiti Tun Hussein Onn, 86400 Parit Raja, Batu Pahat Johor, Malaysia

3 Department of Biochemistry and Molecular Biology, Faculty of Medicine and Health Sciences, Sana'a University, Yemen

4 Department of Human Anatomy, Faculty of Medicine and Health Sciences, Universiti Putra Malaysia, 4340o UPM, Serdang, Selangor, Malaysia

5 Department of Pathology, Faculty of Medicine and Health Sciences, Universiti Putra Malaysia, 43400 UPM, Serdang, Selangor, Malaysia

To cite this article: Abdul Mutalib M, Rahmat A, Ali F, Othman F, Ramasamy R. Nutritional compositions and antiproliferative activities of different solvent fractions from ethanol extract of Cyphomandra betacea (tamarillo) fruit. Malays J Med Sci. 2017;24(5):19-32. https://doi.org/10.21315/mjms2017.24.5·3

To link to this article: https://doi.org/10.21315/mjms2017.24.5.3

\section{Abstract}

Background: This study aims to examine various solvent extracts of Cyphomandra betacea (tamarillo) also known as the tree tomato, for their bioactive constituents and antioxidant activity. The study also aims to examine its effect on cancer cell death using two types of cancer cell lines (liver and breast cancer cell).

Methods: The first part of the study evaluates the nutritional composition of tamarillo. Then, phytochemical profiling using GC-MS analysis in ethanolic tamarillo extract was conducted. Different fractions of $n$-butanol, ethyl acetate and aqueous fractions were obtained from the ethanolic extract of tamarillo. Then, the fractions were subjected to the quantification of total phenol (TPC) and flavonoid contents (TFC), free radical scavenging activity (SA) and also antioxidant activity (AOX) assayed by beta-carotene bleaching (BCB) assay. Finally, the capability of the ethanolic extract of tamarillo and different fractions were evaluated for their anticancer properties.

Results: Findings from this study revealed that the nutritional composition (ash, protein, carbohydrate and total dietary fiber), and mineral levels (calcium, magnesium, potassium and iron) of tamarillo were moderate. The crude ethanol extract of tamarillo contained the highest phenolic and total flavonoid content. FT-IR analysis revealed the presence of alkanes, carboxylic acid, phenol, alkanes, carboxylic acids, aromatics and nitro compounds. Twelve bioactive constituents in tamarillo have been identified through GC-MS analysis. Cytotoxic activity suggests the potential of ethanolic extracts of tamarillo having a chemopreventive effect on breast and liver cancer cells.

Conclusion: This study reveals that tamarillo has substantial antioxidant activity as well as anticancer properties.

Keywords: Cyphomandra betaceae, nutritional composition, antioxidant activity, anticancer activities, antiproliferative activities 


\section{Introduction}

The release of reactive oxygen species (ROS) such as nitric oxide (NO), hydroxyl radical $(\mathrm{OH})$, hydrogen peroxide $\left(\mathrm{H}_{2} \mathrm{O}_{2}\right)$, and superoxide anions $\left(\mathrm{O}_{2}^{-}\right)$from an impaired mitochondrial respiratory chain plays a crucial role in oxidative stress (OS). The term OS can be well-defined when the production of ROS and antioxidants is unstable, which leads to several pathological conditions including cancer, cardiovascular disease, neurodegenerative diseases and metabolic dysfunction of several important organs (1). Free radicals attack important macromolecules such as proteins, lipids and nucleic acids that cause the alteration of these molecules. They later develop a risk of mutagenesis (2). Destruction of the cell structure may lead to cancer initiation and progression by increasing DNA mutation, genome instability and cell proliferation (3).

Excessive amounts of ROS are regulated by a complex system of antioxidant defenses which can be classified under two categories; i) enzymatic antioxidants such as catalase, superoxide dismutase (SOD) and glutathione peroxidase (GPx) and, ii) non-enzymatic antioxidants such as vitamin $\mathrm{D}$, glutathione (GSH) and ascorbic acid (4). Antioxidants act by scavenging free radicals which helps to prevent cellular damage. Chemopreventive properties of antioxidants are hypothesised to minimise carcinogenesis triggered by oxidative stress through direct scavenging activity or by its inhibitory killing properties (5).

Plant metabolites have powerful antioxidant properties which function as free radical scavengers or by reducing redox imbalance. Their chemopreventive properties include blocking, reversing or preventing ROS attack on DNA, alteration of the metabolism of precarcinogens and enhancement of DNA repair. Plant materials contain ubiquitous bioactive compounds that act by blocking the beginning step of carcinogenesis (initiation), which helps to prevent the development of primary tumors (6).

Cyphomandra betaceae or tree tomato (more familiarly known as tamarillo) belongs to the Solanaceae family. Commonly known as 'buah cinta' among the locals, tamarillo is considered to be an undervalued fruit in Malaysia. The type which is available in Malaysia can be easily grown at Cameron Highlands, Pahang (7). Tamarillos are egg-shaped, with a diameter of about 9-12 cm, with reddishbrown skin and orange flesh depending on the maturity. Its seeds are coated with purple or dark red mucilage. The seed of the fruit is consumed together flesh (8). Tamarillo is rich in anthocyanins and carotenoids which are responsible for their colour. The presence of anthocyanins and carotenoids show its biological, therapeutic, and preventative properties (9).

\section{Materials and Methods}

\section{Food Sampling and Sample Preparation}

Ripe tamarillo fruits were collected from Cameron Highlands, Pahang, Malaysia, in June 2013. The herbarium specimens were identified and deposited in the Biology Tropical and Conservation Institute, Universiti Malaysia Sabah, Malaysia. The fruits were washed thoroughly to remove any debris, then weighed and cut into uniform sizes. They were then freeze-dried and ground into a powder. The powdered samples were put through a sieve and kept in a freezer $\left(-20{ }^{\circ} \mathrm{C}\right)$ until further investigation.

\section{Nutritional Composition and Mineral Analyses}

Analysis of nutritional composition was accomplished using the routine method of the Association of Official Analytical Chemists (AOAC) (10) whereas mineral contents were established using atomic absorption spectrometry (AAS). Total protein and fat content were estimated using the Kjeldahl and Soxhlet method, respectively (11).

\section{Antioxidant Vitamins}

\section{Extraction of vitamin A ( $\beta$-carotene)}

Beta-carotene extraction was performed using high performance liquid chromatography (HPLC) analysis following the described method (12). Approximately $3 \mathrm{~g}$ of freeze-dried ground samples were mixed with $10 \mathrm{~mL}$ of freshly prepared ascorbic acid solution (10\%) and 50 $\mathrm{mL}$ of potassium hydroxide $(\mathrm{KOH})$ in an aqueous ethanolic solution (2M). The mixed solution was further refluxed in boiling water for $30 \mathrm{~min}$. Following saponification, the flasks were kept cool at room temperature $\left(25{ }^{\circ} \mathrm{C}\right)$ and hexane (70 $\mathrm{mL}$ ) was added, followed by continuous stirring for 2 minutes. The superior layer was then moved to separating funnel comprising 50 $\mathrm{mL}$ of $5 \%(\mathrm{w} / \mathrm{v}) \mathrm{KOH}$ solution. The extraction processes were repeated twice with $35 \mathrm{~mL}$ 
of hexane. The collective hexane extract was washed away with $100 \mathrm{~mL}$ of $10 \%(\mathrm{w} / \mathrm{v})$ sodium chloride and with consecutive distilled water $(100 \mathrm{~mL})$ until free from alkali. The collected solution was vapourised to dryness using a rotary evaporator at $37^{\circ} \mathrm{C}$. The remainder was liquefied in chloroform and methanol (1:1) that make up to $2 \mathrm{~mL}$.

\section{Extraction of vitamin C (ascorbic acid)}

Extraction of ascorbic acid (AA) was performed using an altered method of Abdulnabi et al.'s (13). Fine powders of tamarillo (10g) were homogenised with $2 \%$ meta-phosphoric acid (50 $\mathrm{mL}$ ) and filtered through a Whatman No. 1 filter paper.

\section{HPLC Analysis}

Analyses of beta-carotene (12) and AA (13) was performed using a reverse phase HPLC with Hewlett Packard HPLC system (HP1100) equipped with an Agilent 1100 series standard auto-sampler, degasser, quaternary pump and a UV-visible detector. For beta-carotene analysis, aliquots $(20 \mu \mathrm{L})$ was injected into a Vydac $20 \mathrm{i} \mathrm{TP}$ 54 reverse-phase $\mathrm{C}_{18}(5 \mu, 25 \times 0.46 \mathrm{~cm})$ at $30{ }^{\circ} \mathrm{C}$. The mobile phase (MP) comprised of acetonitrile (ACN) containing tetrahydrofuran, methanol and $0.6 \%$ of triethylamine at 80:14:6:0.1 (v/v/v/v). A flow rate of $1.0 \mathrm{~mL} / \mathrm{min}$ was used for elution and monitoring at $450 \mathrm{~nm}$. The AA analysis was performed using HPLC system of a Hewlett Packard with diode array detector (DAD). The column used was an Ultrasphereoctadecylsilyl (ODS) Hypersil $\mathrm{C}_{18}(5 \mu, 4.0 \mathrm{~mm} \times 250 \mathrm{~mm})$ column while the MP consisted of a combination of $\mathrm{ACN}$ and water (50:50). The mobile phase was pumped at a flow rate of $1.0 \mathrm{~mL} / \mathrm{min}$ at 20 ${ }^{\circ} \mathrm{C}$ and samples were monitored at $254 \mathrm{~nm}$. The results were estimated from three individual experiments in order to produce statistically significant results.

\section{GC-MS Analysis}

\section{Sample Preparation}

The freeze dried sample of tamarillo (10 g) was weighed and transferred to a round-bottom flask, extracted with ethanol and incubated overnight and filtered (Whatman No.4) with $2 \mathrm{~g}$ of sodium sulfate $\left(\mathrm{Na}_{2} \mathrm{SO}_{4}\right)$ to eliminate residues and a detectable amount of water (14). The extract was then saturated to $1 \mathrm{~mL}$ using nitrogen gas. The ethanolic extracts of tamarillo
( $2 \mu \mathrm{L}$ ) were employed for GC-MS study, executed using a SHIMADZU QP5050A GC-MS system comprising an AOC-20s auto-sampler and equipped with a Mass Spectrometer which range from $\mathrm{m} / \mathrm{z} 46$ to 350 u.m.a. The column of $\mathrm{ZB}$ FFAP $(0.25 \mu \mathrm{m}, 30 \times 0.25 \mathrm{~mm})$ was used. The sample extracts $(4 \mu \mathrm{L})$ were injected into the instrument. Helium gas (99.99\%) at a flow rate of $1.5 \mathrm{~mL} / \mathrm{min}$ was used and the temperature incline began at $50{ }^{\circ} \mathrm{C}$, and raised to $235{ }^{\circ} \mathrm{C}$ and held at $255{ }^{\circ} \mathrm{C}$. Ionisation was achieved by electron impact (EI) at $70 \mathrm{eV}$ and each experiment was repeated for three times.

\section{Components Identification}

The comparative proportion quantity in percentage (\%) was measured by matching the average peak area with the database of the National Institute of Standard and Technology (NIST). The standard name, molecular weight and formula structure of the constituents were established (14).

\section{FT-IR Spectroscopic Analysis}

The ethanolic extracts of tamarillo were examined under an FTIR spectrophotometer to classify the major functional groups that exist in the bioactive complexes. The tamarillo extract was spun at $3000 \mathrm{rpm}$ for $10 \mathrm{~min}$ and filtered with a filter paper (Whatmann No. 1) using high pressure vacuum pump. Later, the sample was scanned using ultraviolet ranges between 4000 to $400 \mathrm{~cm}^{-1}$. The FTIR peak values were documented and the spectral data achieved was matched with the reference table to identify the functional groups present in the sample. Each experiment was repeated three times.

\section{Sample Preparation}

Approximately $1 \mathrm{~g}$ of the freeze-dried sample was extracted for three times using 25 $\mathrm{mL}$ of ethanol at room temperature $\left(25^{\circ} \mathrm{C}\right)$ for $24 \mathrm{~h}$ and filtered through filter paper (Whatmann No. 4). After drying by evaporation at $50{ }^{\circ} \mathrm{C}$, the ethanol fraction was dissolved again in dimethyl sulfoxide (DMSO) and signified as the crude ethanolic extract. The remaining fraction was then made into a water suspension and fractionated with ethyl acetate, n-butanol, and water for 3 times, respectively. Three fractions were obtained after removal of the solvents. The ethyl acetate layer was gathered and vaporised under vacuum at $50{ }^{\circ} \mathrm{C}$ and liquefied in DMSO and signified as the ethyl acetate fraction. The 
n-butanol layer was evaporated at $60{ }^{\circ} \mathrm{C}$ and liquefied in DMSO and signified as the n-butanol fraction. Finally, the water layer was freeze dried and liquefied in DMSO and signified as water fraction (15). These supernatants were later employed for the quantification of total phenolic content (TPC), total flavonoid content (TFC), $\beta$-carotene bleaching (BCB) and diphenylpicrylhydrazyl (DPPH) radical scavenging assays. The absorbance was measured by ultraviolet-visible (UV-Vis) spectrophotometer (SECOMAM, Ales, France) using DMSO as blank. Following that, the ethanolic and its different fractions were further analysed for their antiproliferative activity assayed by MTT assay.

\section{Total Phenolic and Flavonoid Contents}

The TPC was quantified following method adapted from (16) with slight modifications. Briefly, supernatants $(100 \mu \mathrm{l})$ at different concentrations $(20,40,60,80$, and $100 \mu \mathrm{g} / \mathrm{mL}$ ) were mixed with $1.5 \mathrm{~mL}$ of $10 \%$ Folin-Ciocalteu reagent. After 1 minute, $1.5 \mathrm{~mL}$ of a $60 \mathrm{~g} / \mathrm{L}$ sodium carbonate $\left(\mathrm{Na}_{2} \mathrm{CO}_{3}\right)$ solution was added and set aside at room temperature $\left(25{ }^{\circ} \mathrm{C}\right)$ for 90 minutes in the dark. Finally, absorbance was measured at $725 \mathrm{~nm}$. The TPC were expressed as milligram gallic acid equivalent per gram ( $\mathrm{mg}$ GAE/g DW samples) in dry weight samples.

Quantification of TFC was carried out following a modified method as described by Dewanto et al. (17). Concisely, $1 \mathrm{~mL}$ of the crude and different fractions were mixed with $2 \%$ of aluminium chloride hexahydrate $\left(\mathrm{AlCl}_{3} \cdot 6 \mathrm{H}_{2} \mathrm{O}\right)$ in ethanol. The mixtures were kept aside for 10 minutes at room temperature $\left(25^{\circ} \mathrm{C}\right)$ and the reading was measured at $430 \mathrm{~nm}$. The TFC was calculated against quercetin standard calibration curve, which was plotted at 20,40,60,80, and $100 \mu \mathrm{g} / \mathrm{mL}$. Results were expressed as milligram of quercetin equivalents $(\mathrm{QE}) / \mathrm{g}$ DW.

\section{Antioxidant Activity (AOX)}

\section{Beta-Carotene Bleaching Assay (BCB)}

The BCB method was performed according to the described method (18). A standard, beta-carotene $(0.2 \mathrm{mg} / \mathrm{mL})$ was prepared by diluting in chloroform, and the beta-carotene solution $(1 \mathrm{~mL})$ was mixed with linoleic acid (20 $\mu \mathrm{L})$ and Tween $20(200 \mu \mathrm{L})$ and then mixed with the sample extracts $(200 \mu \mathrm{L})$. The chloroform residual was evaporated using a rotary evaporator at $40{ }^{\circ} \mathrm{C}$, and distilled water
(100 $\mathrm{mL}$ ) was added to the mixture. The samples were then capped and incubated in a water bath at $50{ }^{\circ} \mathrm{C}$. The absorbance was measured at $470 \mathrm{~nm}$ at 15 minute time intervals for 2 hours. DMSO was used as blank (lack of beta-carotene) while butylated hydroxyl toluene (BHT) was used as standard control. The percentage (\%) of AOX was calculated using the following formula (16): Degradation rate (DR) of beta-carotene = $\left.\mathrm{Ln}\left[\mathrm{Ab}_{\mathrm{o}} / \mathrm{Ab}_{\mathrm{t}}\right]\right) / 120$ and $(\% \mathrm{AOX})=\left[\left(\mathrm{DR}_{\text {control }}-\right.\right.$ $\left.\mathrm{DR}_{\text {sample }} / \mathrm{DR}_{\text {control }}\right] \times 100$,

Where $\mathrm{Ln}$ is natural logarithm, $\mathrm{Ab}_{\mathrm{o}}$ is the reading measured at $\mathrm{o}$ min while $A b_{t}{ }^{0}$ is the reading of absorbance at time $\mathrm{T}$, where $\mathrm{t}$ is 15 , $30,45,60,75,90,105$ or 120 mins.

\section{Free Radical Scavenging Activity (SA)}

The SA was performed following an altered method described by Lim and Tee (19). Two hundred $\mu \mathrm{L}$ of each fraction in various concentration $(1,2,4,8 \mathrm{mg} / \mathrm{mL})$ of ascorbic acid (standard) $(10,20,40,80 \mu \mathrm{g} / \mathrm{mL})$ were mixed with $100 \mu \mathrm{M}$ DPPH $(1 \mathrm{~mL})$. The mixed solution was agitated uniformly and left in a dark room for $25 \mathrm{~min}$ at room temperature (25 ${ }^{\circ} \mathrm{C}$ ). The optical density (OD) was monitored at $517 \mathrm{~nm}$. Radical scavenging was expressed in percentage (\%) terms and calculated using the formula: \% $\mathrm{SA}=\left(\mathrm{A}_{\text {control }}-\mathrm{A}_{\text {sample }}\right) / \mathrm{A}_{\text {control }} \times 100$. Results were presented as $\mathrm{IC}_{50}$ value, which is the concentration of the samples needed to decrease the DPPH free radical concentration by $50 \%$.

\section{Cell cultures}

Hepatocellular carcinoma tissue (HepG2), breast adenocarcinoma (MDA-MB-231) and non-cancerous mouse fibroblast ( $3 \mathrm{~T}_{3}$ ) cell lines were obtained from the American Type Culture Collection (ATCC, VA, USA). The cells were cultured in an RPMI-1640 media containing 10\% fetal calf serum and $1 \%$ penicillin/streptomycin and incubated in a $5 \% \mathrm{CO}_{2}$ incubator at 37 ${ }^{\circ} \mathrm{C}$ humidified atmospheres in $75 \mathrm{~cm}^{2}$ flasks. Adherent cells (80\%) were detached using 0.25\% (w/v) trypsin-EDTA for analysis.

\section{3-(4,5-dimethylthiazol-2yl)-2,5- diphenyltetrazolium bromide (MTT) assay}

Cell viability was determined by measuring the amount of purple formazan formed by using MTT assay. One hundred microliter of 
cell suspension $\left(1 \times 10^{5}\right.$ cells $\left./ \mathrm{mL}\right)$ were seeded into 96-well plates and incubated at $37^{\circ} \mathrm{C}$ with humidity in a $5 \% \mathrm{CO}_{2}$ incubator atmosphere to attach for $24 \mathrm{~h}$ prior to the addition of samples. Sample extracts $(100 \mu \mathrm{L})$ in concentrations of $6.25,12.5,25,50,100,200 \mu \mathrm{g} / \mathrm{mL}$ were performed through serial twofold dilutions of the crude ethanolic extract and different fractions. Cells were also treated with doxorubicin (0.20, 0.39, 0.78, 1.56, 3.13, 6.25, 12.5, $25 \mu \mathrm{g} /$ $\mathrm{mL}$ ) served as a positive control while culture medium was used as negative control. After $72 \mathrm{~h}$ of treatment, MTT reagent $(10 \mu \mathrm{L})$ was added followed by the solubilisation solution. Absorbance was measured on an ELISA plate reader at $550 \mathrm{~nm}$. All experiments were performed in triplicates. The dose-response curve was plotted by comparing the OD of the treated cells with the control. A concentration displaying $50 \%$ inhibition of cell growth $\left(\mathrm{IC}_{50}\right)$ was estimated.

\section{Statistical Analysis}

Data are presented as mean values \pm standard deviation (S.D). ANOVA with Pearson's Correlation Coefficient was done using SPSS for Windows version 21.0. The significant values were considered at the level of $P<0.05$.

\section{Results and Discussion}

\section{Nutritional Composition}

Table 1 demonstrates the nutritional composition of tamarillo. High content of moisture and ash were reported for tamarillo. The high content of moisture in the samples suggested that they have high perishability (20), while a high amount of ash present is interrelated to the quantity of minerals present in the samples (21).

\section{Minerals Determination by AAS}

Minerals are essential in human nutrition (22). Table 1 displays the mineral composition of tamarillo. Minerals such as $\mathrm{Ca}, \mathrm{Mg}, \mathrm{K}$ and Fe were found in moderate quantities in the tamarillo. $\mathrm{Na}$ and $\mathrm{K}$ are vital intracellular and extracellular cations. $\mathrm{Na}$ is responsible in the control of plasma volume, acid-base stability, muscle and nerve contraction while $\mathrm{K}$ is important for its diuretic function (23). The result shows that $\mathrm{Na}$ was the most abundant element found in tamarillo, concurring with a study reported by Akpanyung (11).

\section{Antioxidant Vitamins}

\section{Beta-carotene and ascorbic acid (AA) contents}

As shown in Table 1, beta-carotene contents were expressed in $\mathrm{mg} / 100 \mathrm{~g}$ DW. Statistical analysis revealed a high beta-carotene content of tamarillo. Saupi et al. (24) reported betacarotene content in purple-red and goldenyellow varieties as 5.2 and $3.4 \mathrm{mg} / 100 \mathrm{~g} \mathrm{FW}$ respectively, thus agreeing with the present study.

AA is a water-soluble vitamin, and it is known as an oxygen scavenger, acting as reducing agent (25). The result showed that tamarillo has high AA content as shown in Table 1. Literature has reported that the AA content in tamarillo range between 25 to $30 \mathrm{mg} / 100 \mathrm{~g} \mathrm{FW}$ and displays a significantly greater Total Oxygen Scavenging Capacity (TOSC) value, possibly because of the presence of anthocyanins (26). Dawes (23) also reported large ranges of vitamin $\mathrm{C}$ levels in tamarillos grown in New Zealand with the red type ranging from 19.3 to $41.6 \mathrm{mg} / 100$ $\mathrm{g}$ and the yellow type ranging from 24.6 to 33.2 $\mathrm{mg} / 100 \mathrm{~g}$. Tamarillo is rich in beta-carotene and AA content, which makes them good as natural sources of pro-vitamin A and vitamin C (24). Hence, both the beta-carotene and AA contents in these fruits are suspected to be involved majorly in the antioxidant activity.

\section{GC-MS Compositions}

Phytochemical analysis of tamarillo identified using GC-MS chromatogram shows the existence of 12 compounds that has numerous benefits in the prevention of human pathologies. After evaluation through matching the mass spectra of the components with the NIST library, there were 5 major phytoconstituents with therapeutic benefits found, which are 5-(Hydroxymethyl)-2-furancarboxaldehyde (57.40\%), 2-Methyl[1,3,4]oxadiazole (6.73\%), 2,3-Dihydro-3,5-dihydroxy-6-methyl-4H-pyran4-one (4.30\%), 2-Furancarboxaldehyde,5methyl (1.92\%), and propanoic acid (1.26\%). Hexadecanoic acid (0.9\%), furfural (0.86\%), thiazole (0.81\%) and acetic acid (0.33\%) were found to be the minor constituents that possess many important phytoconstituents. A previous study done by Torrado et al. (25) identified 46 volatile constituents in tamarillo with the main ones being 4-allyl-2,6-dimethoxyphenol, (Z)hex-3-en-1-ol, methyl hexanoate, (E)-hex-2-enal 
and eugenol. The other identified constituents comprised combination of both methyl-3hydroxybutanoate and 2-butanol.

Table 2 presents the phytochemical properties of the ethanolic extracts of tamarillo, referring to Dr. Duke's Phytochemical and Ethnobotanical Databases (27). Among those identified phytochemicals in the tamarillo ethanolic extract are 2-Methyl[1,3,4] oxadiazole (Figure 1a), 2,3-Dihydro-3,5-dihydroxy-6methyl-4H-pyran-4-one (Figure $1 \mathrm{~b}$ ) and thiazole. These may have a role in anti-inflammatory effects while hexadecanoic acid (Figure 1c) may have a role in antioxidant activities. 1,3,4-Oxadiazole (OXD) products are well-known for their anti-inflammatory (28), antibacterial, antifungal (29) and HIV replication inhibition (30). Furthermore, thiazole was also reported previously to have anticancer properties which suggest the potential of tamarillo.

\section{FT-IR Analysis}

The FT-IR spectrum was employed to classify the major functional groups of the active constituents in tamarillo as shown in Table 3. The FT-IR spectrum established the existence of aromatics and nitro compounds, carboxylic acids, alkanes and also phenols. This paper reports a synchronised approach for the analysis of signals from FT-IR and GC-MS.

\section{Total Phenolic Content}

A Folin-Ciocalteu assay is based on the redox reaction between the Folin-Ciocalteu reagent with all or most phenolics in the sample. The TPC values are presented in Figure 2a and expressed as milligram gallic acid equivalent per gram (mg GAE/g DW) in dry weight samples. Statistical analysis points to that the crude ethanolic extract of tamarillo $(2.53 \mathrm{mg}$ GAE/g DW) comprises significant amounts of polyphenol as assayed by the Folin-Ciocalteu reagent followed by n-butanol $(2.10 \mathrm{mg} \mathrm{GAE} / \mathrm{g}$ DW), ethyl acetate (1.77 mg GAE/g DW) and water fraction (1.49 $\mathrm{mg} \mathrm{GAE} / \mathrm{g} \mathrm{DW}$ ).

Previous work done by Kou et al. (15) found that the EA fraction of tamarillo displayed the highest TPC of $61.1 \mathrm{mg}$ (CE)/g DW which was in contrast with the present study. Nevertheless, a study done by Vasco et al. (25) reported that the TPC values were 1.25 and $1.87 \mathrm{mg} \mathrm{GAE} / \mathrm{g}$ FW in golden-yellow and purple-red tamarillo varieties respectively, which concurs with the present study.

Phenolic compounds are generally liable on the total phenolic groups which respond in a different way with the Folin-Ciocalteu reagent (31). According to Zhang et al. (32), the extraction of polyphenol from plant material is in proportion to the correspondence of phenolic compounds in the solvent, therefore when the compounds are best matched in polarity with the solvent they will be easily extracted. The present outcomes suggest that tamarillo phenolics show wide-ranging solubility in solvents with various polarities. Additionally, Al-Farsi and Lee (33) concluded that ethanol is more efficient in extracting phenolic compounds associated to polar fibrous conditions.

\section{Total Flavonoid Content}

Quantitative determination of TFC is performed using the aluminum chloride colourimetric method and was expressed as quercetin equivalent (mg QE/g DW) as shown in Figure 2b. A previous study reported that $\mathrm{TFC}$ of tamarillo in $80 \%$ methanol extractions were $2.41 \mathrm{mg}$ rutin equivalent (RE)/g (34). This was in agreement with the present study that shows that water extraction resulted in a very low effect for TFC. From the results, it was obvious that the ethanol extraction showed significantly higher TFC values in comparison to water extraction. This is due to the ability of ethanol to alter polyphenol oxidases and cause degradation to the cell wall, thus extracting more endocellular constituents compared to extraction using water alone. In parallel, TFC decreased in tamarillo samples with different fractions with the increased polarity of the partition solvent; n-butanol $>$ ethyl acetate $>$ water fraction.

\section{Antioxidant Capacity}

\section{Beta-Carotene Bleaching Activity (AOX)}

The antioxidant activity (AOX) determined by beta-carotene bleaching (BCB) assay is based on the ability of the antioxidant in the sample extracts in neutralising free radicals. In this study, butylated hydroxyl toluene (BHT) was used as a standard whereas DMSO, which contains no antioxidant components, was used as a control for comparison with different samples. Table 4 shows the statistical analysis of AOX in tamarillo. The ethanol crude extract of tamarillo had the highest AOX, and the orders of the AOX are as follows: Ethanol $>$ n-butanol $>$ ethyl acetate $>$ water. However, tamarillo extract had a lower AOX than BHT (95.60 $\pm 1.7 \%)$.

The sample with the least beta-carotene DR demonstrated the maximum AOX. Seemingly, 
each of the ethanolic and different fractions had lower AOX than the standard ( $\alpha$-tocopherol) had. The highest AOX was detected in tamarillo crude ethanol extract. Theoretically, beta-carotene in the systems goes through a fast discoloration without antioxidant and vice versa. The occurrence of various antioxidant compounds can decelerate the $\mathrm{BCB}$ rate by counteracting the linoleate free radical produced in the system (35). It shows that the degradation level of the linoleate majorly depends on the AOX in the extracts. The results indicated that the control had extensive beta-carotene oxidation, consequently causing the OD to decrease rapidly. However, both of the sample extracts with the existence of various antioxidant compounds preserved their color and OD for an extended time.

\section{DPPH Scavenging Activity (SA)}

This assay measures the capability of the extract in donating electron to reduce DPPH free radicals, thereby bleaching its typical purple color. The extract with the highest $\mathrm{IC}_{50}$ value exhibits the lowest scavenging activity and vice versa. In this study, ascorbic acid was used as a standard at various concentrations $(10,20,40$ and $80 \mu \mathrm{g} / \mathrm{mL}$ ). Similarly, both of the sample extracts were prepared at various concentrations of $1,2,4,8 \mathrm{mg} / \mathrm{mL}$ in DMSO.

Statistical analysis as shown in Table 4 indicated that the $\mathrm{IC}_{50}$ values of the n-butanol fraction of tamarillo had the lowest $\mathrm{IC}_{50}$ to scavenge the stable DPPH radical. This shows that tamarillo exhibited a strong scavenging activity. There are several ways in which naturally occurring phytochemicals act as primary antioxidants (36). The reaction with oxygen, superoxide anion and lipid peroxyl radicals is part of their defense mechanisms. The DPPH scavenging assay is a broadly used method to estimate antioxidant capacity in the short-run (37). A previous study reported by Kou et al. (15) found that the EA fraction of tamarillo demonstrated the most powerful SA (0.089 mg/ $\mathrm{mL}$ ).

\section{Correlations between TPC, TFC, Antioxidant Capacity and Antioxidant Vitamins}

Results from Pearson's Correlation Coefficient reveal a strong correlation between AOX and TPC $(r=0.998, P<0.01)$ as well as
TPC with TFC content $(r=1.000, P<0.01)$. Ghasemzadeh et al. (38) found that the strong positive relationship between TPC and AOX seems to be common in several plant types. Similarly, there was a strong relationship between AOX with TFC $(r=0.997, P<0.01)$. The TPC, TFC and vitamin $C$ were greatly correlated with $\mathrm{DPPH}$ radical scavenging activity $\left(\mathrm{IC}_{50}\right)(r=$ $0.877),(r=0.888)$ and $(r=0.874)$, respectively. The results revealed that TPC, TFC and vitamin $\mathrm{C}$ intensely contributed to the scavenging activity of the tamarillo ethanolic extract.

\section{MTT assay}

The cytotoxic activity of tamarillo was evaluated using MTT assay on selected human cancer cell lines. The sample extract of different fractions was tested in concentrations ranging from $3.125-200 \mu \mathrm{g} / \mathrm{mL}$. The tamarillo extract was able to inhibit the proliferation of HepG2 with the lowest $\mathrm{IC}_{50}$ exhibited by the crude ethanol extract followed by the n-butanol fraction, ethyl acetate fraction and water fraction (Table 5). Ordóñez et al. (39) reported that tamarillo reduced oxidative stress in HepG2 cells and caused apoptosis in a dose-dependent manner. In addition, tamarillo was also able to induce cytotoxicity in MDA-MB-231 with the best $\mathrm{IC}_{50}$ values demonstrated by the crude ethanol extract followed by the ethyl acetate fraction, the n-butanol fraction and the water fraction.

The cytotoxic effect test was also performed on a normal mouse fibroblast cell (3T3) for comparison purpose. All the sample extracts however did not exert any significant cytotoxic effect against $3 \mathrm{~T} 3$ normal cell $\left(I C_{50}>200.00\right.$ $\mu \mathrm{g} / \mathrm{mL}$ ). Doxorubicin (chemotherapy drug) was capable of inducing cytotoxicity in HepG2 and MDA-MB-231 with $\mathrm{IC}_{50}$ value of 0.35 and 0.78 $\mu \mathrm{g} / \mathrm{mL}$, respectively. However, results proved that doxorubicin showed superior cytotoxic activity against $3 \mathrm{~T} 3$ normal cell with $\mathrm{IC}_{50}$ value of $8.00 \mu \mathrm{g} / \mathrm{mL}$. It is shown that different extracts of tamarillo had noteworthy dose-dependent inhibition on the proliferation and viability of the MDA-MB 231 and HepG2 cancer cell lines. It is worth mentioning that the cytotoxic effects of the tamarillo extract against the MDA-MB231, HepG2 and $3 T_{3}$ cells are as good as the effect of commercially used anticancer drug like doxorubicin with improved selectivity (Table 5). 
Table 1. Nutritional composition of tamarillo

\begin{tabular}{cc} 
Analyses & Content per 100 g editable portion \\
Moisture (g) & $85.20 \pm 0.36$ \\
Ash (g) & $1.30 \pm 0.01$ \\
Crude protein (g) & $1.60 \pm 0.20$ \\
Crude fat (g) & $0.00 \pm 0.70$ \\
Carbohydrate (g) & $11.90 \pm 1.54$ \\
Total Dietary Fibre (g) & $6.00 \pm 2.50$ \\
Calcium (mg) & $11.20 \pm 0.70$ \\
Sodium (mg) & $17.80 \pm 3.10$ \\
Magnesium (mg) & $25.20 \pm 0.02$ \\
Potassium (mg) & $410.60 \pm 1.30$ \\
Iron (mg) & $0.30 \pm 1.20$ \\
Analyses & Concentration (mg/100g DW) \\
Beta-carotene (Vitamin A) & $4.80 \pm 0.10$ \\
Ascorbic acid (Vitamin C) & $55.90 \pm 1.30$ \\
\hline
\end{tabular}

Data represent mean $\pm \mathrm{SD}$ of triplicate determinations.

Table 2. Phytocomponents identified in ethanolic extract of tamarillo using GC-MS

\begin{tabular}{|c|c|c|c|c|c|c|}
\hline No & Compound & $\mathbf{R T}$ & MF & MW & $\%$ & ${ }^{* *}$ Activity \\
\hline 1 & Acetic acid & 7.42 & $\mathrm{C}_{2} \mathrm{H}_{4} \mathrm{O}_{2}$ & 60 & 0.33 & Bactericidal effects \\
\hline 2 & Furfural & 8.21 & $\mathrm{C}_{5} \mathrm{H}_{4} \mathrm{O}_{2}$ & 96 & 0.86 & $\begin{array}{l}\text { Used as a flavor in foods, and in } \\
\text { other products, such as cosmetics, } \\
\text { fragrance, pesticide, herbicide, } \\
\text { fungicide, insecticide and } \\
\text { germicide }\end{array}$ \\
\hline 3 & $\begin{array}{l}\text { 2-Methyl }[1,3,4] \\
\text { oxadiazole }\end{array}$ & 8.22 & $\mathrm{C}_{3} \mathrm{H}_{4} \mathrm{~N} 2 \mathrm{O}$ & 84 & 6.73 & $\begin{array}{l}\text { 1,3,4-Oxadiazole (OXD) } \\
\text { derivatives are associated } \\
\text { with many types of biological } \\
\text { properties such as anti- } \\
\text { inflammatory, antibacterial, } \\
\text { antifungal activities, and HIV } \\
\text { replication inhibition. }\end{array}$ \\
\hline 4 & $\begin{array}{l}\text { 2-Furancarboxaldehyde, } \\
\text { 5-methyl }\end{array}$ & 10.32 & $\mathrm{C} 6 \mathrm{H} 6 \mathrm{O} 2$ & 110 & 1.92 & Flavor \\
\hline 5 & Thiazole & $14 \cdot 70$ & $\mathrm{C}_{3} \mathrm{H}_{3} \mathrm{NS}$ & 85 & 0.81 & $\begin{array}{l}\text { Antibacterial, anti-HIV, } \\
\text { hypertension, anti-inflammatory, } \\
\text { anticancer, and anti-convulsant }\end{array}$ \\
\hline 6 & $\begin{array}{l}\text { Bicyclo[2.2.2] octane-4- } \\
\text { carboxylic acid }\end{array}$ & 21.35 & $\mathrm{C} 9 \mathrm{H} 14 \mathrm{O} 2$ & 154 & 1.28 & No report \\
\hline 7 & $\begin{array}{c}\text { 2-Furancarboxylic acid, } \\
\text { hydrazide }\end{array}$ & 22.58 & $\mathrm{C}_{5} \mathrm{H} 6 \mathrm{~N} 2 \mathrm{O} 2$ & 126 & 2.03 & No report \\
\hline 8 & $\begin{array}{l}\text { 2,3-Dihydro-3,5- } \\
\text { dihydroxy-6-methyl- } \\
\text { 4H-pyran-4-one }\end{array}$ & 31.12 & $\mathrm{C} 6 \mathrm{H}_{8} \mathrm{O} 4$ & 144 & 4.30 & Antimicrobial, anti-inflammatory \\
\hline
\end{tabular}


Original Article | Health benefits of Cyphomandra betacea

Table 2. (continued)

\begin{tabular}{|c|c|c|c|c|c|c|}
\hline No & Compound & RT & MF & MW & $\%$ & **Activity \\
\hline 9 & Propanoic acid & 33.40 & $\mathrm{C}_{3} \mathrm{H}_{6} \mathrm{O} 2$ & 74 & 1.26 & $\begin{array}{l}\text { Lowers fatty acids content in } \\
\text { liver and plasma, reduces food } \\
\text { intake, exerts immunosuppressive } \\
\text { actions and probably improves } \\
\text { tissue insulin sensitivity }\end{array}$ \\
\hline 10 & $\begin{array}{l}\text { 5-(Hydroxymethyl)- } \\
\text { 2-furancarboxaldehyde }\end{array}$ & 40.82 & $\mathrm{C} 6 \mathrm{H}_{6} \mathrm{O} 3$ & 126 & 57.40 & Antimicrobial preservative \\
\hline 11 & n-Hexadecanoic acid & 59.17 & $\mathrm{C}_{16} \mathrm{H}_{32} \mathrm{O} 2$ & 256 & 0.90 & $\begin{array}{l}\text { Antioxidant, hypocholesterolemic, } \\
\text { nematicide, pesticide, lubricant, } \\
\text { antiandrogenic, flavor, haemolytic }\end{array}$ \\
\hline 12 & $\begin{array}{l}\text { 9,12-Octadecanoic acid } \\
\text { (z, z)-methyl } \\
\text { ester }\end{array}$ & 67.88 & $\mathrm{C}_{19} \mathrm{H}_{34} \mathrm{O} 2$ & 294 & 0.96 & $\begin{array}{l}\text { Anti-inflammatory, cancer } \\
\text { preventive, hepatoprotective, } \\
\text { nematicide,insectifuge, } \\
\text { antihistamine, antieczemic, } \\
\text { anti-acne, 5-alpha reductase } \\
\text { inhibitor, antiandrogenic, } \\
\text { anti-arthritic, anti-coronary }\end{array}$ \\
\hline
\end{tabular}

**Source: Dr.Duke's phytochemical and ethnobotanical databases [Online database]

Table 3. FTIR peak values and functional groups of ethanolic extract of tamarillo

\begin{tabular}{cc} 
Peak values & Functional groups \\
3334.09 & Phenol \\
2925.65 & Alkane \\
1718.87 & Aliphatic acid \\
1402.19 & Aromatic \\
1349.89 & Nitro compound \\
1215.83 & Ether \\
1043.81 & Esters \\
923.23 & Carboxylic acids \\
775.13 & Aromatic \\
\hline
\end{tabular}

Table 4. Antioxidant activity assayed by beta carotene bleaching assay and DPPH scavenging activity

\begin{tabular}{cc} 
Type of fraction & Antioxidant activity (\%) \\
Crude ethanol extract & $79.30 \pm 4.10$ \\
Ethyl acetate fraction & $57.50 \pm 1.14$ \\
n-butanol fraction & $68.60 \pm 1.30$ \\
Water fraction & $55.20 \pm 0.56$ \\
Type of fraction & IC $_{50}$ DPPH $(\mathrm{mg} / \mathrm{mL})$ \\
Crude ethanol extract & $0.80 \pm 4.10$ \\
Ethyl acetate fraction & $1.40 \pm 1.14$ \\
n-butanol fraction & $0.70 \pm 1.30$ \\
Water fraction & $1.75 \pm 0.56$ \\
\hline
\end{tabular}

Data are presented as mean \pm standard deviation of triplicate measurements $(n=3)$ 
Table 5. Cytotoxicity of crude ethanol extract and different fractions against various cell lines

\begin{tabular}{ccc} 
Cell line & Type of fraction & IC $_{50}$ value $(\mu \mathrm{g} / \mathrm{mL})$ \\
HepG2 & Crude ethanol extract & $10.00 \pm 2.00$ \\
& Ethyl acetate fraction & $44.00 \pm 1.60$ \\
n-butanol fraction & $26.00 \pm 3.80$ \\
MDA-MB-231 & Water fraction & $110.00 \pm 1.20$ \\
& Crude ethanol extract & $80.00 \pm 3.40$ \\
& EA fraction & $82.00 \pm 2.00$ \\
& n-butanol fraction & $96.00 \pm 6.00$ \\
$3 \mathrm{~T}_{3}$ & Water fraction & $130.00 \pm 3.60$ \\
\hline
\end{tabular}

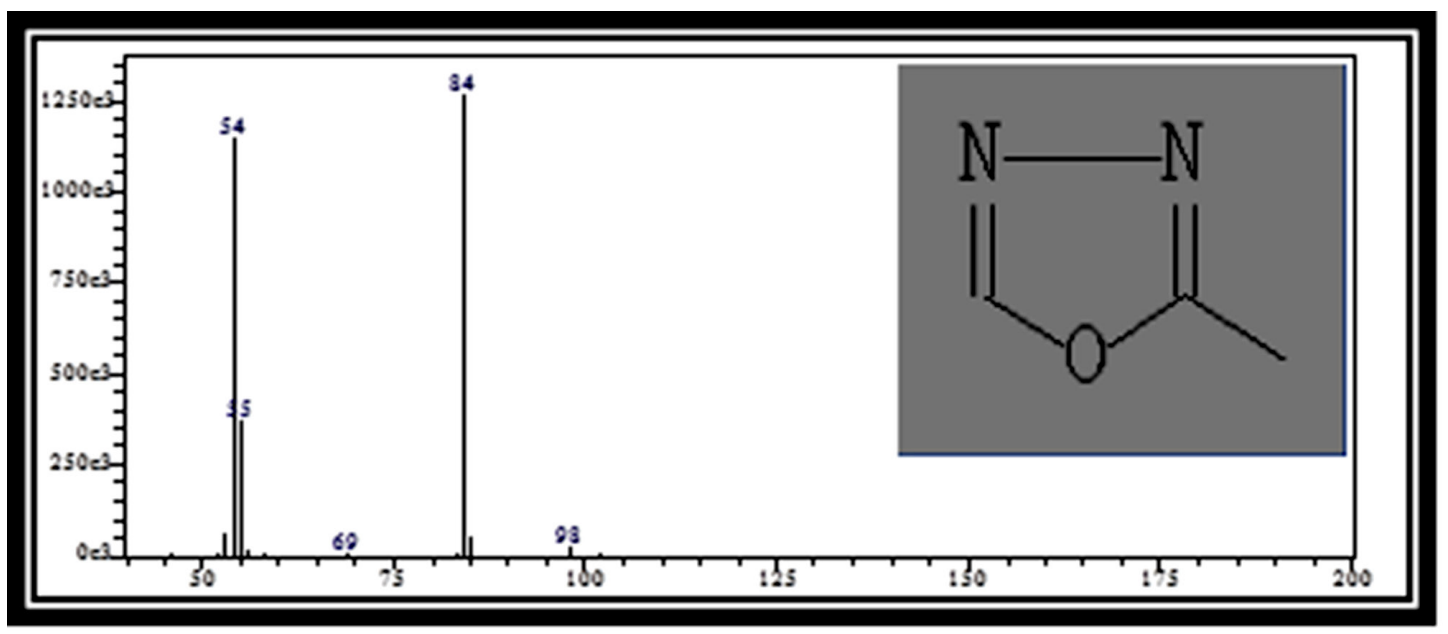

Figure 1(a). Mass spectrum of 2-Methyl[1,3,4] oxadiazole (RT: 8.22)

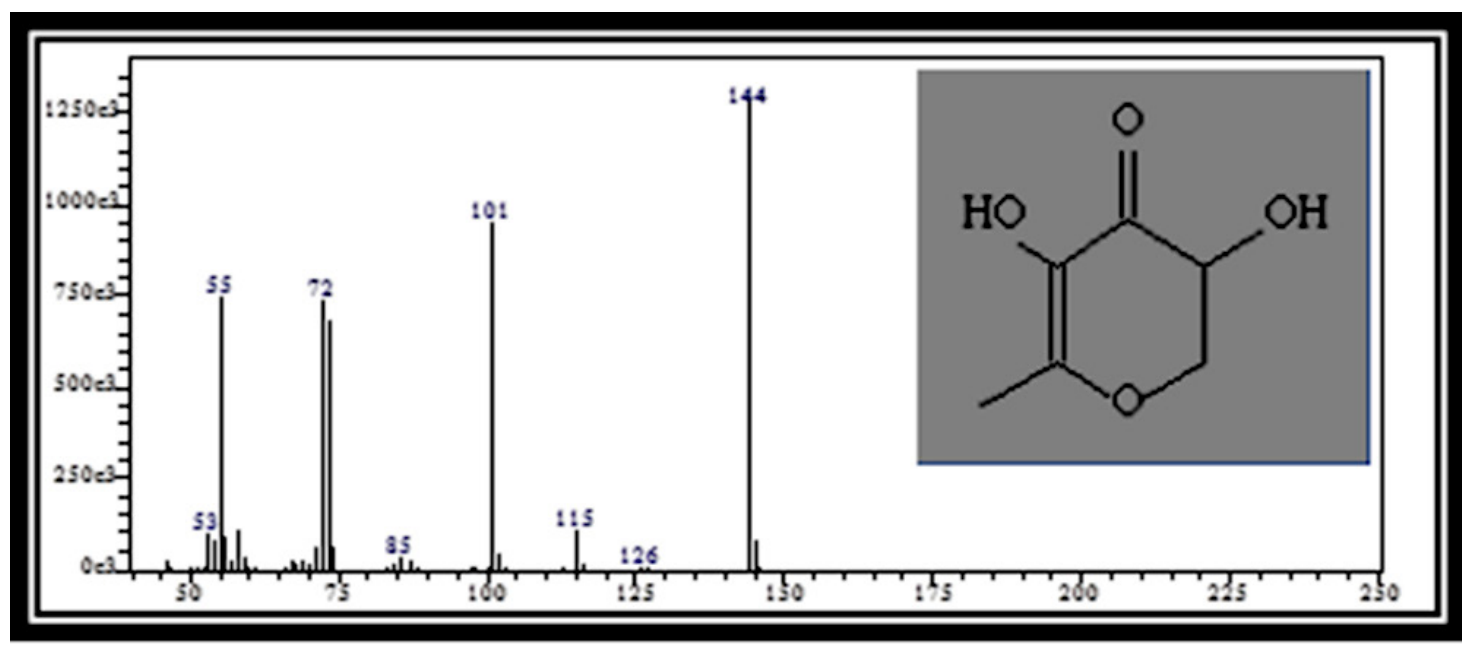

Figure 1(b). Mass spectrum of 4H-Pyran-4-one, 2,3-dihydro-3,5-dihydroxy-6-methyl (RT: 31.13) 


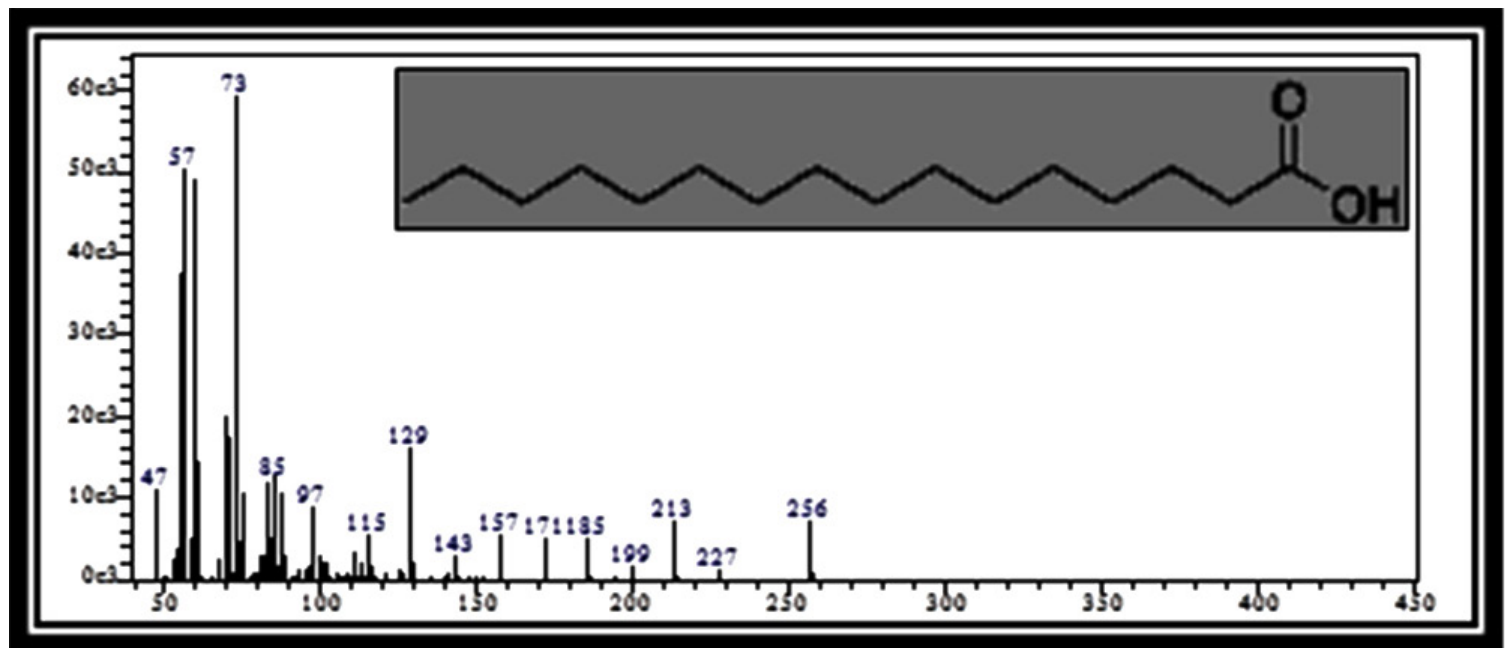

Figure 1(c). Mass spectrum of Hexadecanoic acid (Palmitic acid) (RT: 59.17)

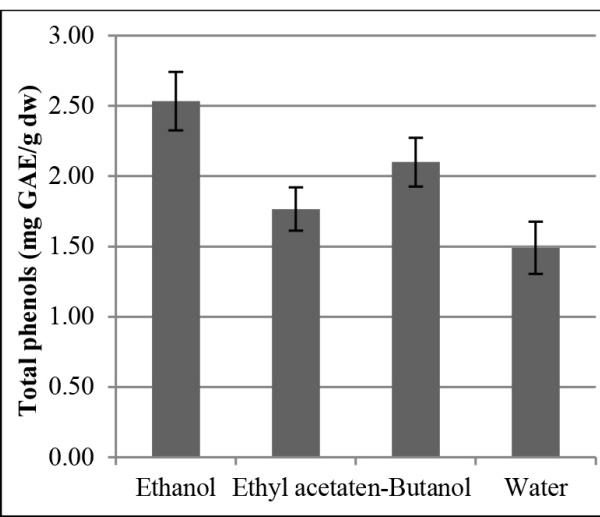

(a)

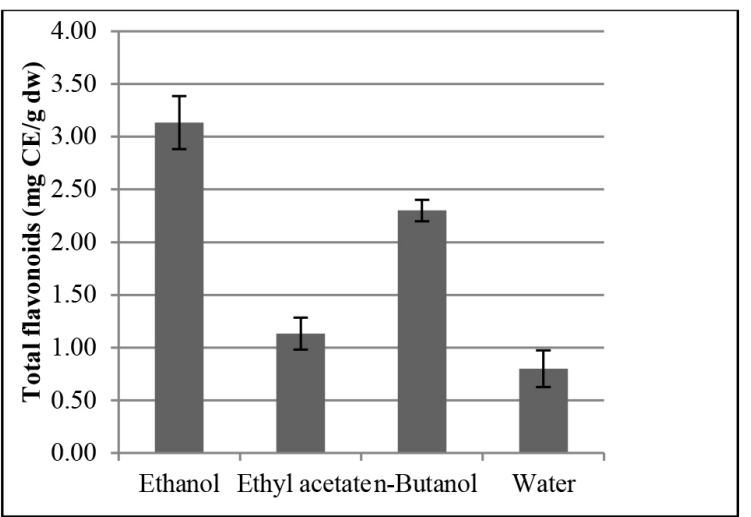

(b)

Figure 2. (a) Total phenolic content and (b) total flavonoid content of tamarillo different fractions. Data are presented as mean \pm standard deviation of triplicate measurements $(n=3)$ 


\section{Conclusion}

In summary, the moisture, ash, carbohydrate, protein and total dietary fiber content were found in moderate amounts in tamarillo. Besides, high antioxidant activity was also observed in the tamarillo. Antioxidant vitamin levels were also significantly high in tamarillo. The scavenging effect of tamarillo was attributed to its superior TPC. In addition, the tamarillo also showed selective cytotoxicity towards liver hepatocellular carcinoma (HepG2) and non-hormone dependent breast carcinoma (MDA-MB-231) but not on Normal mouse fibroblast cells $\left(3 \mathrm{~T}_{3}\right)$. These findings suggest that the tamarillo is potentially a good anti-cancer agent since it is non-toxic towards normal cells. This study proposes that tamarillo may have effective natural antioxidants. It is also acts as a cytotoxic agent against selected cancer cell lines.

\section{Acknowledgements}

This work was supported by a Research Grant from the Universiti Putra Malaysia under Research University Grants (RUGS) (04-02-121759RU).

\section{Authors' Contributions}

Conception and design: MAM, AR, FO, RR

Analysis and interpretation of the data: MAM, FA Drafting of the article: MAM, FA

Critical revision of the article for important intellectual content: AR, FA, FO, RR

Final approval of the article: MAM, AR, FA, FO, RR

Obtaining of funding: AR

Administrative, technical, or logistic support: FA

Collection and assembly of data: MAM

\section{Correspondence}

Dr Asmah Rahmat

Professor in Nutritional Biochemistry,

Faculty of Science Technology and Human Development,

Universiti Tun Hussein Onn,

86400 Parit Raja, Batu Pahat Johor, Malaysia

Tel: 603-8947 2470

Fax: 603-8942 6769

E-mails: asmahr@uthm.edu.my \& fhha39@gmail.com (Dr.Faisal Ali)

\section{References}

1. Birben E, Sahiner UM, Sackesen C, Erzurum $\mathrm{S}$, Kalayci O. Oxidative stress and antioxidant defense. World Allergy Organ. J. 2012;5(1):9-19. https://doi.org/10.1097/WOX.obo13e3182439613

2. Circu ML, Aw TY. Reactive oxygen species, cellular redox systems and apoptosis. Free Radic. Biol. Med. 2010;48(6):749-762. https://doi. org/10.1016/j.freeradbiomed.2009.12.022

3. Lobo V, Patil A, Phatak AN, Chandra N. Free radicals, antioxidants and functional foods: impact on human health. Pharmacogn. Rev. 2010;4(8):118-126. https://doi. org/10.4103/0973-7847.70902

4. Sies H. Oxidative Stress: oxidants and antioxidants. London: Accademic Press; 1991.

5. Ali F, Ranneh Y, Ismail A, Esa NM. Identification of phenolic compounds in polyphenols-rich extract of Malaysian cocoa powder using the HPLC-UV-ESI-MS/MS and probing their antioxidant properties. $J$ Food Sci Technol. 2013;54:2103-2111. https://doi.org/10.1007/ s13197-013-1187-4

6. Landis-Piwowar KR, Iyer NR. Cancer chemoprevention: current state of the art. Cancer Growth and Metastasis. 2014;7:19-25. https:// doi.org/10.4137/CGM.S11288

7. Lim TK. Referenced up-to-date-information on nutritive and medicinal properties. Edible medicinal and non-medicinal plants. In: Solanum betaceam. Volume 6. Holland, Netherlands: Springer; 2013. 326-332 p.

8. Morton JF. Fruits of warm climates. Miami: Creative Resource Systems Inc.; 2013.

9. Kong JM, Chia, LS, Goh NK, Chia TF, Brouillard R. Analysis and biological activities of anthocyanins. Phytochem. 2003;64(5):923-933. https://doi.org/ Soo31/j.phytochem.2003.06.001

10. AOAC. Official method of analysis of AOAC. 15th ed. Washington: Association of Official Analytical Chemists; 1990.

11. Akpanyung EO. Proximate and mineral composition of bouillon cubes produced in Nigeria. Pak. J of Nutr. 2005;4(5):327-329. https://doi.org/10.3923/pjn.2005.327.329 
12. Charoensiri R, Kongkachuicha R, Suknicom S, Sungpuag P. Beta-carotene, lycopene, and alpha-tocopherol contents of selected Thai fruits. Food Chem. 2009;113:202-207. https://doi. org/10.1016/j.foodchem.2008.07.074

13. Abdulnabi AA, Emhemed AH, Hussein GD, Biacs PA. Determination of antioxidant vitamins in tomatoes. Food Chem. 1997;60:207-212. https:// doi.org/10.1016/So308-8146 (96)oo321-4

14. Ezhilan BP, Neelamegam R. GC-MS analysis of phytocomponents in the ethanol extract of Polygonumchinense L. Pharmacognosy Res. 2012;4(1):11-14. https://doi.org/10.4103/09748490.91028

15. Kou MC, Yen JH, Hong JT, Wang CL, Lin CW, Wu MJ. Cyphomandra betacea Sendt. Phenolics protect LDL from oxidation and PC12 cells from oxidative stress. Food Sci. Technol. 2009;42:458-463. https://doi.org/10.1016/j. lwt.2008.09.010

16. Velioglu YS, Mazzaand GL, Oomah BD. Antioxidant activity and total phenolics in selected fruits, vegetables, and grain products. J. Agric. Food Chem. 1998;46(10):4113-4117. https://doi.org/10.1021/jf9801973

17. Dewanto V, Wu X, Adom KK, Liu RH. Thermal processing enhances the nutritional value of tomatoes by increasing total antioxidant activity. J. Agric. Food Chem. 2002;50(10): 3010-3014. https://doi.org/10.1021/jfo115589

18. Al-Saikhan MS, Howard LR, Miller JRJC. Antioxidant activity and total phenolics in different genotypes of potato (Solanumtuberosum L.). J. Food Sci. 1995;60:341-343. https://doi. org/ org/10.1186/1472-6882-13-243

19. Lim YY, Tee JJ. Antioxidant properties of guava fruit: comparison with some local fruits. Sunway Academic Journal. 2006;3:9-20. https://doi. org/10.1016/So308-8146(96)oo321-4

20. Adeleke RO, Abiodun OA. Physico-chemical properties of commercial local beverages in Osun state, Nigeria. Pak J of Nutr. 2010;9:853-855. https://doi.org/10.3923/pjn.2010.853.855

21. Coimbra MC, Jorge N. Proximate composition of guariroba (Syagrus oleracea), jerivá (Syagrus romanzoffiana) and macaúba (Acrocomia aculeata) palm fruits. Food Res Int. 2011;44:2139-2142. https://doi.org/10.1016/j. foodres.2011.03.032
22. Ibanga OI, Okon DE. Minerals and anti-nutrients in two varieties of African pear (Dacryodesedulis). Food Technol. 2009;7(4):106-110. https://doi. org/jftech.2009.106.110

23. Dawes SN. Processing potential and composition of New Zealand sub-tropical fruits. Food Tech in New Zealand. 1972;22-27. https://doi. org/10.1111/j.1745-4514.1988.tboo363.x

24. Saupi N, Zakaria MH, Bujang JS. Analytic chemical composition and mineral content of yellow velvetleaf (Limnocharisflava L. Buchenau's) edible parts. J. Applied Sci. 2009;9:2969-2974. https://doi.org/10.3923/ jas.2009.2969.2974

25. Vasco C, Avila J, Ruales J, Svanberg U, KamalEldin A. Physical and chemical characteristics of golden-yellow and purple-red varieties of tamarillo fruit (Solanum betaceum Cav.). Int. $J$. Food Sci.Nutr. 2009;60:278-280. https://doi. org/10.1016/j.foodchem.2016.08.015

26. Roberts W, Gordon M. Determination of the total antioxidant activity of fruits and vegetables by a liposome assay. J. Agric. Food Chem. 51:2003;1486-1493. https://doi.org/10.1021/ jfo25983t

27. Torrado A, Suárez M, Duque C, Krajewski D, Neugebauer W, Schreier P. Volatile constituents from tamarillo (Cyphomandra betacea Sendtn.) fruit. Flav. Frag. J. 1995;10(6):349-354. https:// doi.org/10.1007/978-94-007-5628-1_38

28. Tan TMC, Chen Y, Kong KH, Li Y, Lim SG, Ang TH. Synthesis and the biological evaluation of 2-benzenesulfonylalkyl-5-substituted-sulfanyl$[1,3,4]$-oxadiazoles as potential anti-hepatitis B virus agents. Antiviral Res. 2006;71:7-14. https://doi.org/10.1016/j.antiviral.2006.02.007

29. El-Emam AA, Al-Deeb OA, Al-Omar M, Lehmann J. Synthesis, antimicrobial, and anti-HIV-1 activity of certain 5-(1-Adamantyl)-2-substituted thio-1,3,4-oxadiazoles and 5-(1-Adamantyl)-3substituted aminomethyl-1,3,4-oxadiazoline-2thiones. Bioorg. Med. Chem. 2004;12:5107-5113. https://doi.org/10.1016/j.bmc.2004.07.033

30. Sahlin E, Savage GP, Lister CE. Investigation of the antioxidant properties of tomatoes after processing. J. Food Comp. Anal. 2004;17:635647. https://doi.org/10.3923/ajps.2012.217.225 
31. Singleton VL, Orthofer R, Lamuela-Raventos RM. Analysis of total phenols and other oxidation substrates and antioxidants by means of Folin-Ciocalteu reagent. Methods Enzymol. 1999;299:152-179. https://doi.org/10.1016/ Soo76-6879(99)99017-1

32. Zhang Z, Li D, Wang L, Ozkan, N Chen XD, Mao Z, Yang H. Optimization of ethanolwater extraction of lignans from flaxseed. Sep. Purif. Technol. 2007;57(1):17-24. https://doi. org/10.1631/jzus.B1200365

33. Al-Farsi MA, Lee CY. Optimization of phenolics and dietary fiber extraction from date seeds. Food Chem. 2008;108:977-985. https://doi. org/10.1016/j.foodchem.2007.12.009

34. Ali Hassan SH, Abu Bakar MF. Antioxidative and anticholinesterase activity of Cyphomandra betacea fruit. Scientific World J. 2013;2013:1-7. https://doi.org/10.1155/2013/278071

35. Jayaprakasha GK, Singh RP, Sakariah KK. Antioxidant activity of grape seed (Vitisvinifera) extracts on peroxidation models in vitro. Food Chem. 2001;73:285-290. https://doi. org/10.1016/So308-8146(oo)00298-3
36. Helmja K, Vaher M, Püssa T, Kamsol K, Orav A, Kaljurand M. Bioactive components of the hop strobilus. J. Chromatogr. 2007;1155:222-229. https://doi.org/10.1016/j.chroma.2006.12.067

37. Re RPN, Proteggente A, Pannala A, Yang M and Rice-Evans C. Antioxidant activity applying an improved ABTS radical cationdecolorization assay. Free Radic. Biol. Med. 1999;26(910):1231-1237. https://doi.org/10.1016/So8915849(98)oo315-3

38. Ghasemzadeh A, Azarifar M, Soroodi O, Jaafar HZE. Flavonoid compounds and their antioxidant activity in extract of some tropical plants. J. Med. Plants Res. 2012;6(13):2639-2643. https://doi. org/10.5897/JMPR11.1531

39. Ordóñez, RM, Cardozo ML, Zampini IC, Isla MI. Evaluation of antioxidant activity and genotoxicityofalcoholic and aqueous beverages and pomace derivedfrom ripe fruits of Cyphomandra betacea Sendt. J. Agric. Food Chem. 2010;58(1):331-337. https://doi. org/10.1021/jf9024932 